The Canadian Mineralogist

Vol. 42, pp. 1105-1115 (2004)

\title{
STRUCTURAL VARIATION IN THE LITHIOPHILITE-TRIPHYLITE SERIES AND OTHER OLIVINE-GROUP STRUCTURES
}

\author{
Arthur LOSEY, JoHn RAKOVAN AND JoHn M. HUGHES \\ Department of Geology, Miami University, Oxford, Ohio 45056, USA
}

CARL A. FRANCIS

Harvard Mineralogical Museum, 24 Oxford Street, Cambridge, Massachusetts 02138, USA

\section{DARBY DYAR}

Department of Earth and Environment, Mount Holyoke College, South Hadley, Massachusetts 01075, USA

\begin{abstract}
The crystal structures of five natural samples of the lithiophilite-triphylite series $\left[\mathrm{Li}(\mathrm{Mn}, \mathrm{Fe}) \mathrm{PO}_{4} ; \mathrm{Li}=M 1,(\mathrm{Mn}, \mathrm{Fe})=M 2\right]$ were refined to determine structural variation along the $\mathrm{Mn}(\mathrm{r}=0.83 \AA) \Leftrightarrow \mathrm{Fe}(\mathrm{r}=0.78 \AA$ ) solid-solution series, and to elucidate variations in the atomic arrangement of Pbnm olivine. The refinements converged to $R \leq 0.017$. Bonds at the $\mathrm{O} 3$ site are fundamental in understanding the response of the atomic arrangement as Fe concentration increases. The $\mathrm{M} 2-\mathrm{O} 3 \mathrm{a}$ bond shortens by more than $0.06 \AA$, and the $M 2-\mathrm{O} 3 \mathrm{~b}$ bond shortens by $\sim 0.02 \AA$ over the series. This shift of the $\mathrm{O} 3$ oxygen toward the two coordinating $M 2$ sites is commensurate with an increase in the $M 1-\mathrm{O} 3$ bond length by approximately $0.03 \AA$, and an increase in the distortion of the $M 1$ site. Much previous work has focused on polyhedron distortions in the olivine structure. The angle variance for the $M 1, M 2$, and $T$ polyhedra were calculated for each phosphate sample in this study and published silicate and germanate olivine structures. In each case, the angle variance of the phosphate olivines was found to be smaller in the $M 1$ octahedron, which is in contrast to the other olivine-structure phases examined in this study. However, if the size difference in the radius of the $M 1$ and $M 2$ site cations is $\geq 0.17 \AA$, the distortion is greater in the octahedral site that is occupied by the larger cation. The structural differences along the lithiophilite-triphylite solid-solution series may have significant effects on its solid electrolyte properties, including rates of lithium diffusion and activation energies, and thus are important in the development and design of Li-olivine storage cathodes.
\end{abstract}

Keywords: lithiophilite, triphylite, olivine structure, crystal structure, lithium storage electrodes.

\section{SOMMAIRE}

Nous avons affiné la structure cristalline de cinq échantillons naturels faisant partie de la série lithiophilite-triphylite $\left[\mathrm{Li}(\mathrm{Mn}, \mathrm{Fe}) \mathrm{PO}_{4} ; \mathrm{Li}=M 1,(\mathrm{Mn}, \mathrm{Fe})=M 2\right]$ afin de déterminer la variation structurale le long de la série à mesure que le $\mathrm{Mn}$ (rayon $0.83 \AA$ ) remplace le Fe (rayon $0.78 \AA$ ), et pour élucider les agencements atomiques d'une olivine Pbnm. Les affinements ont convergé à un résidu $R \leq 0.017$. Les liaisons impliquant le site $\mathrm{O} 3$ sont fondamentales pour expliquer la réponse de l'agencement atomique à mesure que la proportion de Fe augmente. La liaison $M 2-\mathrm{O} 3 \mathrm{a}$ est raccourcie de plus de $0.06 \AA$, et la liaison $M 2-\mathrm{O} 3 \mathrm{~b}$ est raccourcie d'environ $0.02 \AA$ le long de la série. Ces déplacements de l'atome $\mathrm{O} 3$ vers les deux sites $M 2$ dans l'agencement sont conformes avec une augmentation de la longueur de $M 1-\mathrm{O} 3$ d'environ $0.03 \AA$, et du degré de distorsion du site $M 1$. Plusieurs travaux antérieurs ont porté sur les distorsions des polyèdres dans la structure d'une olivine. Nous avons calculé la variance des angles des polyèdres $M 1, M 2$, et $T$ pour chaque échantillon de phosphate dans ce travail et pour les structures d'olivine parmi les compositions de silicates et de germanates. Dans chaque cas, la variance des angles dans les phosphates à structure d'olivine s'avère plus faible pour l'octaèdre $M 1$, ce qui diffère du cas des autres structures d'olivine examinées ici. Toutefois, si la différence dans le rayon du cation aux sites $M 1$ et $M 2$ est $\geq 0.17 \AA$, la distorsion est plus grande dans le site octaédrique qu'occupe le plus gros cation. Les différences structurales le long de la série lithiophilite-triphylite pourraient bien avoir des effets importants sur ses propriétés électrolytiques, y inclus les taux de diffusion du lithium et les énergies d'activation, et donc elles pourraient être importantes dans le développement et le dessin de cathodes pour le stockage de lithium dans une structure de type olivine.

(Traduit par la Rédaction)

Mots-clés: lithiophilite, triphylite, structure d'une olivine, structure cristalline, électrodes pour stockage de lithium.

$\S \quad$ E-mail address: rakovajf@muohio.edu 


\section{INTRODUCTION}

Minerals of the lithiophilite-triphylite series $\left[\mathrm{Li}(\mathrm{Mn}, \mathrm{Fe}) \mathrm{PO}_{4}\right]$ occur in evolved granitic pegmatites that are enriched in both $\mathrm{Li}$ and $\mathrm{P}$. These phases are isostructural with olivine (Fig. 1). Members of the series forsterite - fayalite are abundant in mafic igneous rocks and are of utmost importance in the upper mantle. Various other olivine-group minerals occur in rocks with very diverse geochemical histories (Brown 1980), attesting to the importance of understanding the atomic arrangement of olivine.

In this study, single-crystal X-ray-diffraction experiments were performed on natural lithiophilite-triphylite samples with $\mathrm{Fe} /(\mathrm{Mn}+\mathrm{Fe})$ values of $06,27,50,79$, and 89 (referred to as Trip06, etc.). The atomic arrangement of each sample was refined to elucidate the structural changes with composition in this series. Structural information for end-member triphylite, Trip100, was taken from Streltsov et al. (1993).
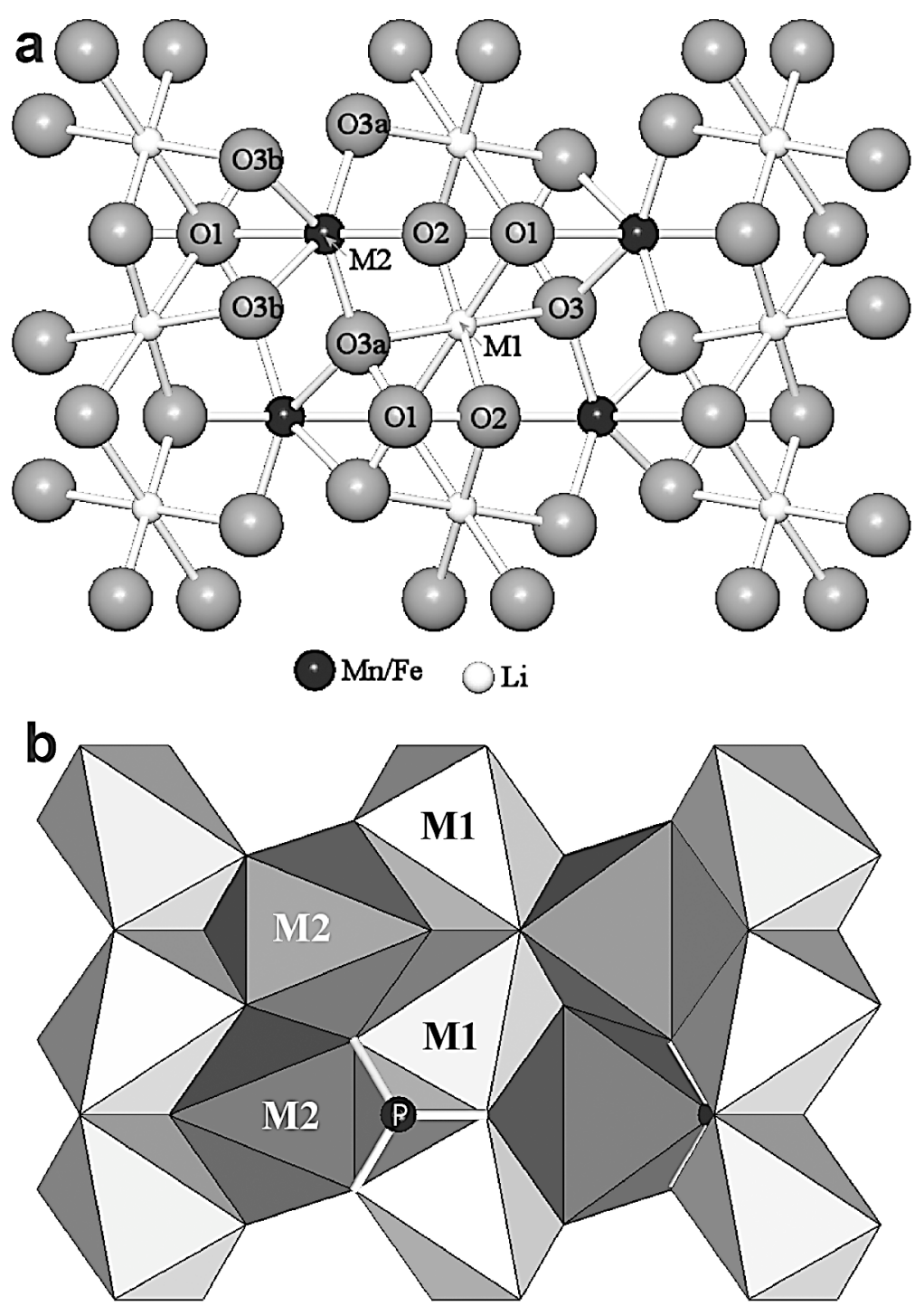

FIG. 1. (100) projection of the lithiophilite-triphylite crystal structure. a) Ball-and-stick representation. b) Polyhedron representation, with P site ball-and-stick. 


\section{BACKGROUND INFORMATION}

Recently, there has been considerable interest in the Li-phosphate olivine, triphylite, as a storage cathode for rechargeable lithium batteries. Key to the use of this phase in batteries are its electrical and ion (Li) conductivity. Triphylite, as well as other phases adopting the olivine structure, is an electrical insulator, which is the main impediment to its use in batteries. Chung et al. (2002), however, have shown that controlled cation nonstoichiometry combined with doping can increase the electrical conductivity of triphylite by as much as $10^{8}$, well above that of Li storage cathodes currently used in commercially available batteries. They postulated that in a conventional design of a cell, triphylite may yield the highest power density yet developed in rechargeable Li batteries. Furthermore, they speculated that the same doping mechanism for increasing electrical conductivity in triphylite will apply to other phases adopting the olivine structure, such as lithiophilite. Structural changes in triphylite due to solid solutions with iron may have significant effects on its solid electrolyte properties, including rates of $\mathrm{Li}$ diffusion and activation energies. Thus knowledge of structural changes that result from solid solutions are important in the development and design of Li-based olivine storage cathodes.

Few structural investigations have been performed on members of the lithiophilite-triphylite series, particularly with respect to structural variations that occur along the $\mathrm{Mn} \Leftrightarrow \mathrm{Fe}$ join. In many of the previous singlecrystal X-ray studies, synthetic samples were used (Geller \& Durand 1960, Streltsov et al. 1993, Yakubovich et al. 1977). Structure refinements using natural samples were performed by Finger \& Rapp (1969).

There have also been studies on the relationship between composition and unit-cell parameters (Fransolet et al. 1984, Lumpkin \& Ribbe 1983) in the lithiophilitetriphylite series. Fransolet et al. (1984) attempted to determine the $\mathrm{Mn} /(\mathrm{Mn}+\mathrm{Fe})$ value from powder-diffraction experiments. However, those methods were not found to accurately predict the unit-cell parameters or the divalent cation ratio $\mathrm{Mn} /(\mathrm{Mn}+\mathrm{Fe})$ of our samples. Lumpkin \& Ribbe (1983) and Fransolet et al. (1984) did note a structural variation with composition.

\section{EXPERIMENTAL DETAILS}

\section{Samples}

The five lithiophilite-triphylite samples from internally zoned granitic pegmatites in New England, USA, were obtained from the Harvard University Mineral Museum. Locations, Harvard Museum numbers, and location references are given in Table 1. For sample Trip27, Fillow Quarry, Branchville, Connecticut, is the type location of lithiophilite. The crystals used for data collection are fragments of very large (up to several meters in length) lithiophilite-triphylite crystals.

TABLE 1. CRYSTAL DATA AND RESULTS OF STRUCTURE REFINEMENTS FOR SAMPLES OF THE LITHIOPHILITE - TRIPHYLITE SERIES

\begin{tabular}{|c|c|c|c|c|c|}
\hline Parameter & Trip06 & Trip27 & Trip50 & Trip79 & Trip89 \\
\hline \multirow[t]{2}{*}{ Location } & Bennett Q & Fillow Q & $\mathrm{BB} \# 7 \mathrm{Q}$ & Palermo \#1 Q & G.E. Smith Q \\
\hline & $\begin{array}{r}\text { Buckfield, } \\
\text { Maine }\end{array}$ & $\begin{array}{l}\text { Branchville, } \\
\text { Connecticut }\end{array}$ & $\begin{array}{r}\text { Norway, } \\
\text { Maine }\end{array}$ & $\begin{array}{l}\text { Groton, } \\
\text { New Hampshire }\end{array}$ & $\begin{array}{l}\text { Newport, } \\
\text { New Hampshire }\end{array}$ \\
\hline Harvard \# & 86792 & 134825 & 134209 & 117995 & 97510 \\
\hline Reference & $\begin{array}{l}\text { Landes } \\
(1925)\end{array}$ & $\begin{array}{l}\text { Shainin } \\
\text { (1946) }\end{array}$ & & $\begin{array}{l}\text { Segeler } \text { et al. } \\
(1981)\end{array}$ & $\begin{array}{c}\text { Chapman } \\
(1943)\end{array}$ \\
\hline Size & $\begin{array}{r}115 \times 130 \times \\
130 \mathrm{~mm}\end{array}$ & $\begin{array}{r}130 \times 150 \times \\
180 \mathrm{~mm}\end{array}$ & $\begin{array}{r}115 \times 130 \times \\
150 \mathrm{~mm}\end{array}$ & $\begin{array}{r}200 \times 160 \times \\
160 \mathrm{~mm}\end{array}$ & $\begin{array}{r}160 \times 180 \times \\
200 \mathrm{~mm}\end{array}$ \\
\hline$a(\AA)$ & $4.7383(1)$ & $4.7247(2)$ & $4.7138(6)$ & $4.7006(4)$ & $4.6904(6)$ \\
\hline$b(\AA)$ & $10.429(1)$ & $10.4084(9)$ & $10.3826(1)$ & $10.341(1)$ & $10.2855(9)$ \\
\hline$c(\AA)$ & $6.0923(4)$ & $6.0705(4)$ & $6.0499(5)$ & $6.0166(5)$ & $5.9871(4)$ \\
\hline$V\left(\AA^{3}\right)$ & $301.0(3)$ & $298.5(1)$ & $296.1(1)$ & $292.6(1)$ & $288.8(2)$ \\
\hline Space group & Pbnm & Pbnm & Pbnm & Pbnm & Pbnm \\
\hline Theta range & $1-30^{\circ}$ & $1-31^{\circ}$ & $1-30^{\circ}$ & $0-31^{\circ}$ & $0-31^{\circ}$ \\
\hline Unique reflections & 478 & 511 & 471 & 502 & 494 \\
\hline$R$ merge & 0.014 & 0.014 & 0.015 & 0.012 & 0.027 \\
\hline Reflections with $\mathrm{I}>3 \sigma$ & 386 & 434 & 390 & 452 & 387 \\
\hline$R$ & 0.017 & 0.017 & 0.015 & 0.015 & 0.017 \\
\hline$R w$ & 0.023 & 0.025 & 0.021 & 0.026 & 0.025 \\
\hline
\end{tabular}

Q: quarry. 


\section{Electron-microprobe analysis}

Chemical analyses of the lithiophilite-triphylite samples (Trip06, Trip50, Trip79, and Trip89) were performed on a Cameca MBX electron microprobe using wavelength-dispersion spectrometry in the Department of Earth and Planetary Sciences at Harvard University (Table 2). Beam conditions were: $15 \mathrm{keV}, 23 \mathrm{nA}, 16 \times$ $16 \mu \mathrm{m}$ raster. Sandia BA85 was used as a standard for matrix corrections, assuming 9.5 wt. $\% \mathrm{Li}_{2} \mathrm{O}$. The $K \alpha$ lines were used for all elements. The following standards were used: albite $(\mathrm{Na})$, enstatite $(\mathrm{Mg}, \mathrm{Si})$, apatite $(\mathrm{P}, \mathrm{Ca})$, tephroite $(\mathrm{Mn})$, and fayalite $(\mathrm{Fe})$. A fifth sample, Trip27 (Table 2) was analyzed by electron microprobe at numerous laboratories in a round-robin study; for details, see Dyar et al. (2001).

\section{Collection of X-ray-diffraction data}

Single-crystal fragments of the five lithiophilitetriphylite samples were isolated and ground to 150-200 $\mu \mathrm{m}$ ellipsoids. Each sample was then mounted on an Enraf-Nonius CAD-4 diffractometer utilizing graphitemonochromatized $\mathrm{MoK} \alpha \mathrm{X}$-radiation for data collection of a hemisphere of reciprocal space. Cell parameters (Table 1) were calculated by least-squares refinement of the setting angles of twenty-five automatically centered reflections, each measured at four positions. Crystal data and refinements details are found in Table 1.

\section{Structure refinements}

The SDP for Windows package of programs (Frenz 1997) was used to refine the atomic arrangement, using

\begin{tabular}{|c|c|c|c|c|c|}
\hline & Trip06 & Trip27 & Trip50 & Trip79 & Trip89 \\
\hline $\mathrm{Na}_{2} \mathrm{O} \mathrm{wt}^{\mathrm{t}} \%$ & 0.02 & 0.01 & 0.02 & 0.03 & 0.02 \\
\hline $\mathrm{MgO}$ & 0.02 & 0.05 & 0.02 & 1.42 & 6.15 \\
\hline $\mathrm{SiO}_{2}$ & 0.01 & 0.05 & 0.14 & 0.29 & 0.02 \\
\hline $\mathrm{P}_{2} \mathrm{O}_{5}$ & 44.18 & 46.53 & 43.56 & 43.81 & 45.67 \\
\hline $\mathrm{CaO}$ & 0.08 & 0.04 & 0.01 & 0.00 & 0.00 \\
\hline $\mathrm{MnO}$ & 41.18 & 31.91 & 21.77 & 9.00 & 4.11 \\
\hline $\mathrm{FeO}$ & 2.78 & 12.17 & 22.33 & 34.10 & 32.15 \\
\hline $\mathrm{Li}_{2} \mathrm{O}$ & 9.29 & 8.43 & 9.23 & 9.41 & 9.73 \\
\hline Total & 97.55 & 99.19 & 97.09 & 98.06 & 97.85 \\
\hline $\mathrm{Na}$ apfu & 0.001 & 0.001 & 0.001 & 0.002 & 0.001 \\
\hline $\mathrm{Mg}$ & 0.001 & 0.002 & 0.001 & 0.056 & 0.234 \\
\hline $\mathrm{Si}$ & 0.000 & 0.001 & 0.004 & 0.008 & 0.001 \\
\hline $\mathrm{P}$ & 1.001 & 1.026 & 0.994 & 0.980 & 0.988 \\
\hline $\mathrm{Ca}$ & 0.002 & 0.001 & 0.000 & 0.000 & 0.000 \\
\hline $\mathrm{Mn}$ & 0.933 & 0.704 & 0.497 & 0.201 & 0.089 \\
\hline $\mathrm{Fe}$ & 0.062 & 0.265 & 0.503 & 0.753 & 0.687 \\
\hline $\mathrm{Li}$ & 1.000 & 0.883 & 1.000 & 1.000 & 1.000 \\
\hline
\end{tabular}

Structural formula based on four atoms of oxygen. triphylite as a starting model (Streltsov et al. 1993), I> $3 \sigma_{I}$ data, and neutral-atom scattering factors with terms for anomalous dispersion. Absorption was corrected using $360^{\circ} \Psi$-scan data for three reflections and their Friedel equivalents. A weighting scheme, with weights equal to $4 F_{\mathrm{o}}{ }^{2} / \sigma\left(F_{\mathrm{o}}{ }^{2}\right)^{2}$ and a term to downweigh intense reflections, was used throughout the refinement. In the refinements, $\mathrm{Li}, \mathrm{P}$, and $\mathrm{O} 1-\mathrm{O} 3$ were fixed to fully occupy their respective sites. The $M 1$ site was modeled with $\mathrm{Li}$, and the $M 2$ site was modeled with Mn (Trip06, Trip27, and Trip50) or Fe (Trip79 and Trip89).

The atomic arrangements of the five samples refined routinely. Each of the refinements converged to $R \leq$ 0.017 (Table 1). The release of the $\mathrm{Mn}, \mathrm{Fe}$ site had no significant effect on the structure refinement owing to the similar scattering-factors of $\mathrm{Mn}$ and $\mathrm{Fe}$, with the exception of the Trip89 sample. This sample would only refine to $R \approx 0.032$ before the release of the $M 2$ site occupancy. The refinement improved to $R \approx 0.017$ after the release of the Fe site owing to the significant amount of $\mathrm{Mg}(0.23 a p f u)$ in this sample.

Atomic parameters of the five samples are found in Table 3, and the bond lengths and tetrahedron angles are listed in Table 4 . The anisotropic thermal parameters and structure factors may be obtained from the Depository of Unpublished Data, CISTI, National Research Council of Canada, Ottawa, Ontario K1A 0S2, Canada. The bond-valence sums (Table 5) were calculated for each sample using the method of Brown (1981)

TABLE 3. POSITIONAL PARAMETERS AND ISOTROPIC $B$ VALUES FOR ATOMS IN SAMPLES OF THE LITHIOPHILITE - TRIPHYLITE SERIES

\begin{tabular}{|c|c|c|c|c|c|}
\hline & Trip06 & Trip27 & Trip50 & Trip79 & Trip89 \\
\hline \multirow[t]{4}{*}{$\mathrm{Li}$} & 0.0 & 0.0 & 0.0 & 0.0 & 0.0 \\
\hline & 0.0 & 0.0 & 0.0 & 0.0 & 0.0 \\
\hline & 0.0 & 0.0 & 0.0 & 0.0 & 0.0 \\
\hline & $1.7(1)$ & $1.59(8)$ & $1.50(8)$ & $0.78(6)$ & $1.55(9)$ \\
\hline \multirow{3}{*}{$\begin{array}{r}\mathrm{Mn}, \mathrm{Fe} \\
x \\
y \\
z\end{array}$} & $0.97154(9)$ & $0.97253(8)$ & $0.97362(8)$ & $0.97463(6)$ & $0.9746(1)$ \\
\hline & $0.28163(4)$ & $0.28183(3)$ & $0.28199(3)$ & $0.28200(3)$ & $0.28164(4)$ \\
\hline & 0.25 & 0.25 & 0.25 & 0.25 & 0.25 \\
\hline$B\left(\AA^{2}\right)$ & $0.580(6)$ & $0.558(6)$ & $0.594(5)$ & $0.592(5)$ & $0.593(7)$ \\
\hline \multirow[b]{4}{*}{$B($} & $0.4091(1)$ & $0.4113(1)$ & $0.4138(1)$ & $0.4164(1)$ & $0.4169(2)$ \\
\hline & $0.09238(7)$ & $0.09309(6)$ & $0.09364(6)$ & $0.09448(5)$ & $0.09476(6)$ \\
\hline & 0.25 & 0.25 & 0.25 & 0.25 & 0.25 \\
\hline & $0.52(9)$ & $0.560(9)$ & $0.65(1)$ & $0.419(8)$ & $0.59(1)$ \\
\hline \multirow[t]{4}{*}{01} & $0.7310(5)$ & $0.7343(4)$ & $0.7366(4)$ & $0.7402(4)$ & $0.7412(5)$ \\
\hline & $0.0966(2)$ & $0.0968(2)$ & $0.0969(2)$ & $0.0970(1)$ & $0.0983(2)$ \\
\hline & 0.25 & 0.25 & 0.25 & 0.25 & 0.25 \\
\hline & $0.85(3)$ & $0.85(3)$ & $0.94(3)$ & $0.73(2)$ & $0.83(3)$ \\
\hline \multirow[t]{4}{*}{$\mathrm{O} 2$} & $0.2115(4)$ & $0.2104(4)$ & $0.2089(4)$ & $0.2062(3)$ & $0.2055(4)$ \\
\hline & $0.4558(2)$ & $0.4559(2)$ & $0.4562(2)$ & $0.4570(1)$ & $0.4560(2)$ \\
\hline & 0.25 & 0.25 & 0.25 & 0.25 & 0.25 \\
\hline & $0.78(3)$ & $0.86(3)$ & $0.92(3)$ & $0.65(2)$ & $0.81(3)$ \\
\hline \multirow[b]{4}{*}{$B\left(\AA^{2}\right)$} & $0.2770(3)$ & $0.2787(2)$ & $0.2813(2)$ & $0.2836(2)$ & $0.2827(3)$ \\
\hline & $0.1617(1)$ & $0.1625(1)$ & $0.1635(1)$ & $0.1649(1)$ & $0.1655(1)$ \\
\hline & $0.0494(2)$ & $0.0487(2)$ & $0.0478(2)$ & $0.0472(2)$ & $0.0465(2)$ \\
\hline & $0.79(2)$ & $0.86(2)$ & $0.97(2)$ & $0.69(2)$ & $0.84(2)$ \\
\hline
\end{tabular}


and bond-valence parameters from Brese \& O'Keeffe (1991).

\section{REsults AND Discussion}

\section{Structural variations with composition}

The octahedrally coordinated cations in the lithiophilite-triphylite series are completely ordered between the $M 1$ and $M 2$ sites. Li only occupies the $M 1$ site, whereas the $M 2$ site is occupied by divalent $\mathrm{Mn}, \mathrm{Fe}$ and, in some cases, $\mathrm{Mg}$. Another olivine-group mineral, natrophilite $\left(\mathrm{NaMnPO}_{4}\right)$, is also completely ordered, and is the only ordered olivine-type structure in which the $M 1$ cation is much larger than the divalent $M 2$ cation (Moore 1972). In other ordered olivine-group phases, such as monticellite $\left(\mathrm{MgCaSiO}_{4}\right)$ and glaucochroite $\left(\mathrm{MnCaSiO}_{4}\right)$, the divalent cations in the $M 1$ site are smaller than the cations in the $M 2$ site (Lager \& Meagher 1978). The complete order of cations in these minerals is in contrast to the majority of olivine-structure phases, in which there is extensive disorder among the octahedrally coordinated cations. Although Mn and Fe only occupy the $M 2$ site in the lithiophilite-triphylite series, the solid solution between these two constituents affects both the $M 2$ and $M 1$ sites.

The substitution of $\mathrm{Fe}^{2+}(\mathrm{r}=0.78 \AA$; Shannon 1976) for $\mathrm{Mn}^{2+}(\mathrm{r}=0.83 \AA$; Shannon 1976) in the lithiophilitetriphylite series suggests, by Vegard's law, that a concomitant shortening of the octahedron bond-lengths should occur. Figure 2 confirms that hypothesis; it depicts the variation of $M 2-\mathrm{O}$ bond lengths with composition along the $\mathrm{Mn} \Leftrightarrow \mathrm{Fe}$ join. Note that sample Trip89, which contains substantial amounts of $\mathrm{Mg}$, generally lies off the variation trend of the other samples, indicat-

TABLE 4. BOND LENGTHS $(\AA ̊)$ AND TETRAHEDRON BOND ANGLES $\left(^{\circ}\right)$ FOR SAMPLES OF THE LITHIOPHILITE - TRIPHYLITE SERIES

\begin{tabular}{|c|c|c|c|c|c|}
\hline & Trip06 & Trip27 & Trip50 & Trip79 & Trip89 \\
\hline$M 1-01 \times 2$ & $2.227(1)$ & $2.212(1)$ & $2.199(1)$ & $2.1822(9)$ & $2.175(1)$ \\
\hline$-02 \times 2$ & $2.098(1)$ & $2.094(1)$ & $2.092(1)$ & $2.0904(9)$ & $2.086(1)$ \\
\hline$-\mathrm{O} 3 \times 2$ & $2.158(1)$ & $2.163(1)$ & $2.173(1)$ & $2.1829(8)$ & $2.175(1)$ \\
\hline Mean & 2.161 & 2.156 & 2.154 & 2.1518 & 2.145 \\
\hline$M 2-01 \times 1$ & $2.242(2)$ & $2.230(1)$ & $2.223(1)$ & $2.206(1)$ & $2.181(2)$ \\
\hline$-02 \times 1$ & $2.143(2)$ & $2.132(1)$ & $2.122(1)$ & $2.111(1)$ & $2.095(1)$ \\
\hline$-03 a \times 2$ & $2.127(1)$ & $2.112(1)$ & $2.095(1)$ & $2.0751(9)$ & $2.063(1)$ \\
\hline$-03 b \times 2$ & $2.270(1)$ & $2.264(1)$ & $2.261(1)$ & $2.2514(9)$ & $2.236(1)$ \\
\hline Mean & 2.196 & 2.186 & 2.176 & 2.1617 & 2.146 \\
\hline $\mathrm{P} \quad-01 \times 1$ & $1.525(2)$ & $1.526(1)$ & $1.522(1)$ & $1.522(1)$ & $1.521(2)$ \\
\hline$-02 \times 1$ & $1.535(2)$ & $1.538(1)$ & $1.538(1)$ & $1.535(1)$ & $1.536(1)$ \\
\hline$-03 \times 2$ & $1.551(1)$ & $1.551(1)$ & $1.552(1)$ & $1.5519(9)$ & $1.552(1)$ \\
\hline Mean : & 1.536 & 1.538 & 1.537 & 1.536 & 1.536 \\
\hline $\mathrm{O}(1)-\mathrm{P}-\mathrm{O}(2)$ & $113.48(12)$ & $113.36(10)$ & $113.30(10)$ & $113.07(7)$ & $113.23(11)$ \\
\hline $\mathrm{O}(1)-\mathrm{P}-\mathrm{O}(3)$ & $112.93(7)$ & $113.09(6)$ & $113.07(6)$ & $113.20(4)$ & $113.22(7)$ \\
\hline $\mathrm{O}(2)-\mathrm{P}-\mathrm{O}(3)$ & $106.40(7)$ & $106.31(6)$ & $106.37(6)$ & $106.47(5)$ & $106.48(7)$ \\
\hline $\mathrm{O}(3)-\mathrm{P}-\mathrm{O}(3)$ & $103.92(8)$ & $103.92(7)$ & $103.91(7)$ & $103.68(5)$ & $103.43(8)$ \\
\hline
\end{tabular}

ing that incorporation of the smaller $\mathrm{Mg}$ ion $(\mathrm{r}=0.72$ $\AA$; Shannon 1976) affects the variation in the octahedron bond-lengths to a greater extent.

Although the shortening of the bond lengths involving $M 2$ is expected, the bond-length variations in that polyhedron also induce variations in the $M 1$ polyhedron, occupied solely by Li. Figure 3 depicts the variations of the $M 1-\mathrm{O}$ bond lengths with composition along the $\mathrm{Mn}$ $\Leftrightarrow \mathrm{Fe}$ join. The $M 1-\mathrm{O} 1$ and $M 1-\mathrm{O} 2$ bond lengths decrease, whereas the $M 1-\mathrm{O} 3$ bond length increases with increasing Fe-for-Mn substitution. This change occurs with no substitutions of cations for $\mathrm{Li}$ in the $M 1$ site.

The $M 1$ site is octahedrally coordinated and consists of two symmetrically equivalent bonds to each of the three oxygen atoms. The $M 2$ site also is octahedrally coordinated. However, the $M 2$ site has one bond to each of $\mathrm{O} 1$ and $\mathrm{O} 2$ and four bonds to $\mathrm{O} 3$, with two different lengths (referred to as $\mathrm{O} 3 \mathrm{a}$ and $\mathrm{O} 3 \mathrm{~b}$ ). Figures $2 \mathrm{a}-\mathrm{e}$ and $3 \mathrm{a}-\mathrm{d}$ demonstrate the relationship between the proportion of $\mathrm{Fe}$ and the cation-oxygen bond-lengths. The changes in the bond lengths at the $M 1$ and $M 2$ sites are dependent on the occupancy of the $M 2$ site. However, the changes in bond lengths that occur with the increase in the proportion of $\mathrm{Fe}$ are influenced by $\mathrm{O} 3$ site coordination. We here examine structural changes that occur with respect to $\mathrm{O} 3$.

\section{The $O 3$ site}

The $\mathrm{O} 3$ oxygen is unique among the anion sites in the olivine structure, and is important in understanding the response of the arrangement of atoms to the $\mathrm{Mn} \Leftrightarrow$ Fe substitution at the $M 2$ site in the lithiophilitetriphylite series. The $\mathrm{O} 3$ oxygen is the only anion that bonds to two $M 2$ sites; $\mathrm{O} 1$ and $\mathrm{O} 2$ each bond to only one $M 2$ site.

The largest bond-length variation with cation substitution in the series occurs in the M2-O3a bond (Table 4), which shortens by more than $0.06 \AA$ (Fig. 2c) with substitution of $\mathrm{Fe}$ over the range of $\mathrm{Mn} \Leftrightarrow \mathrm{Fe}$ studied. The M2-O3b bond contracts by $\sim 0.02 \AA$ (Fig. $2 \mathrm{~d}$ ) over the same range of solid solution. Figure 4 characterizes the coordination of $\mathrm{O} 3$ and depicts the changes that occur as Fe substitutes for $\mathrm{Mn}$ at the M2 site.

In addition to bonding to two $M 2$ ions, $\mathrm{O} 3$ also bonds to one $M 1$ cation. Because of the shift of the $\mathrm{O} 3$ oxygen toward the two coordinating $M 2$ sites, the bond to $M 1$ increases in length by approximately $0.03 \AA$ with increasing degree of incorporation of the smaller $\mathrm{Fe}^{2+}$ ion at $M 2$; thus, the shortening of the $M 2-\mathrm{O} 3$ bonds is commensurate with a lengthening of the $M 1-\mathrm{O} 3$ bonds (Fig. 3c). Figure 5 shows the variation of $M 1$ bond-valence sum that occurs with Fe substitution for Mn along the lithiophilite-triphylite series. A best-fit line to this data series (omitting sample Trip89 because of its high $\mathrm{Mg}$ content) was determined by least squares $\left(\mathrm{r}^{2}=\right.$ 0.9412 ), so that the bond-valence sum for end-member lithiophilite and triphylite could be extrapolated. Site $M 1$ 
is underbonded for all compositions, but increases from 0.926 in lithiophilite to 0.953 in triphylite. Thus the bond-valence sum to the $M 1$ site is closest to the formal charge of $\mathrm{Li}^{1+}$ in triphylite, although the two $M 1-\mathrm{O} 3$ bonds increase in length with increasing $\mathrm{Fe}$ along the lithiophilite-triphylite join.

\section{Distortion of the octahedral sites}

Composition varies greatly among phases with the olivine structure, but the $M 1$ and $M 2$ octahedra are distorted regardless of the site occupant (Brown 1980, Fleet
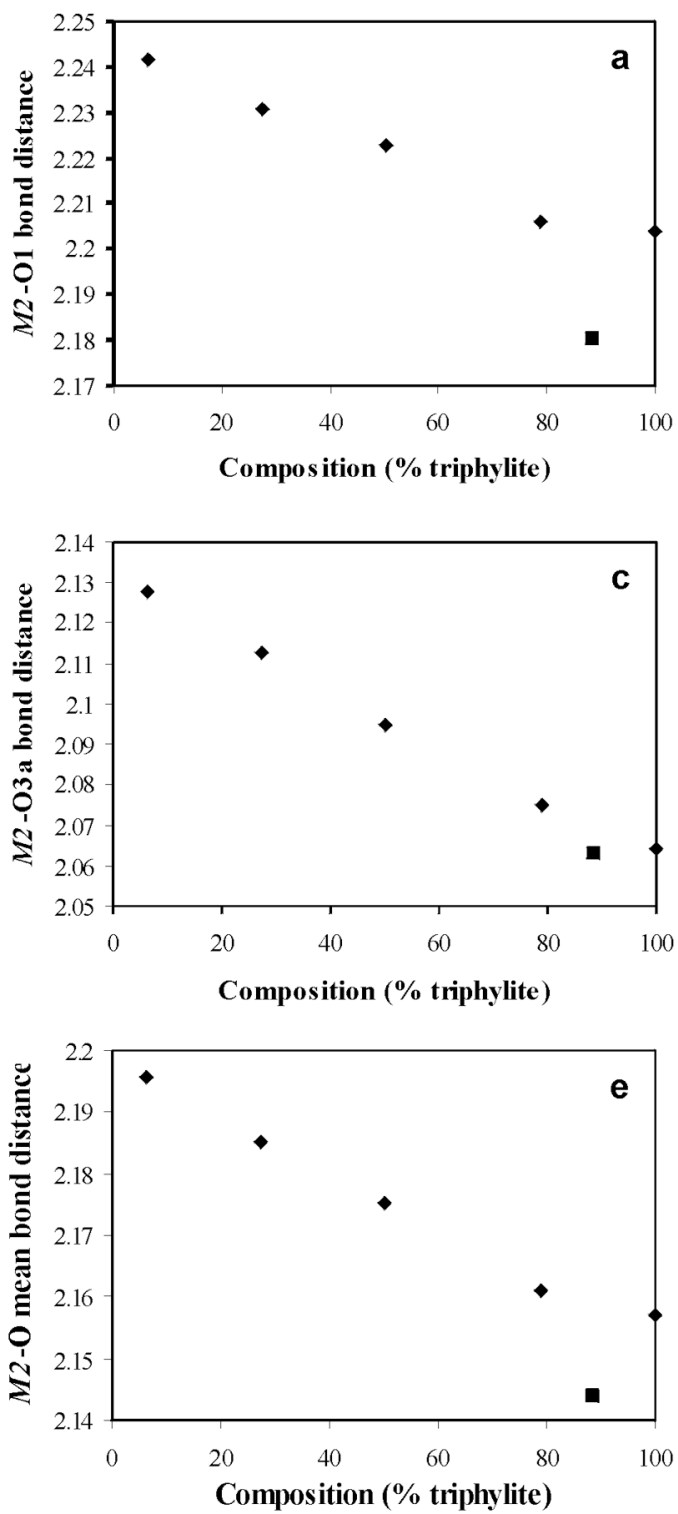

1974). There is a large difference in geometry between the $M 1$ and $M 2$ octahedral sites. The $M 1$ octahedron shares six edges with other polyhedra, two each with $M 1, M 2$, and $T$ polyhedra. The distortion of the $M 2 \mathrm{oc}-$ tahedron is more complex. The $M 2$ occupant is not centered in the $M 2$ octahedron, as is the cation of the centrosymmetric $M 1$ octahedron. This is a response to cation repulsions across the three shared polyhedron edges, two with $M 1$ polyhedra and one with a tetrahedron (Brown 1980, Fleet 1974). The $M 2-T$ repulsive force has the greatest effect on the bond lengths of the M2 octahedron (Brown 1980). This is especially appar-
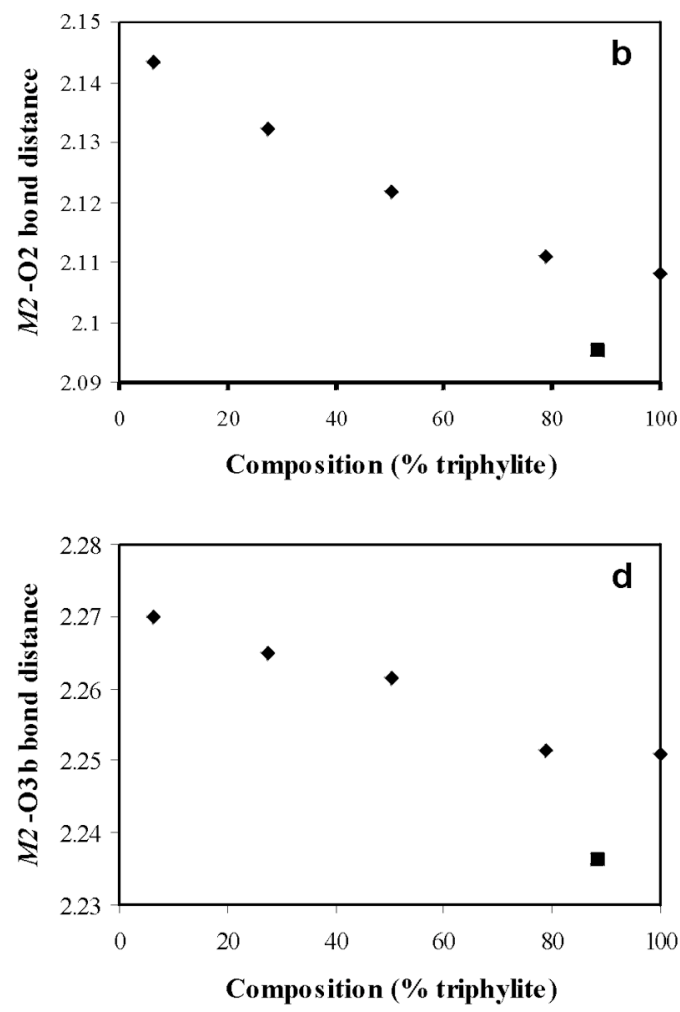

FIG. 2. a-e. Composition versus the bond lengths of the $M 2$ site. Data points encompass error of $1 \sigma . \boldsymbol{\square}$ is the high-Mg sample. 

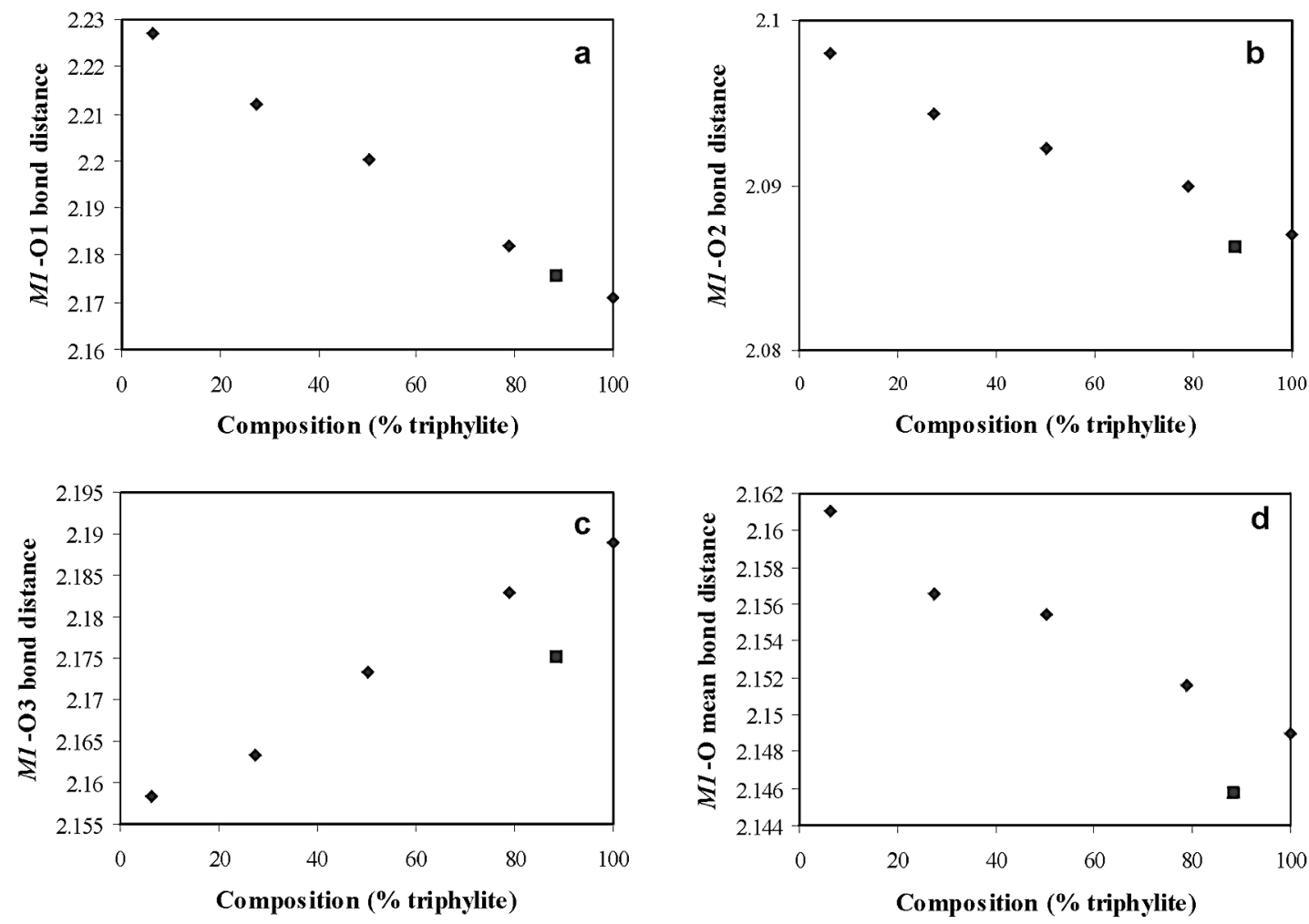

FIG. 3. a-d. Composition versus the bond lengths of the $M 1$ site. Data points encompass error of $1 \sigma . \mathbf{v}$ is the high-Mg sample.

ent in the $M 2-\mathrm{O} 3$ bond lengths and is illustrated in Table 4. The O3b oxygen atom is on the edge shared between the $M 2-T$ polyhedra. The cation repulsion across the $M 2-T$ edge causes the $M 2-\mathrm{O} 3 \mathrm{~b}$ bond to lengthen and concomitantly the opposite $M 2-\mathrm{O} 3$ a bond to shorten to compensate for this cation repulsion.

The angle variance, as defined by Robinson et al. (1971), was used to quantify the distortion of octahedra and tetrahedra in our samples and other olivine-group phases. Robinson et al. (1971) concluded that the $M 1$ octahedron is systematically more distorted than the $M 2$ octahedron, and that angle variance increases as cation size increases in olivine-group minerals. This statement holds true for the angle variance of many olivine-group structures, such as fayalite (Smyth 1975), forsterite (Smyth \& Hazen 1973), Ni-substituted olivine (Lager $\&$ Meagher 1978), and natrophilite (Moore 1972). Conversely, in the lithiophilite-triphylite series, the variance of the octahedral angle for $M 1$ is lower than for $M 2$ in every sample. The angle variance of the end members of the $\mathrm{Mn} \Leftrightarrow \mathrm{Fe}$ solid solution are 144.354(3) ${ }^{\circ 2}$ and $152.153(2)^{\circ 2}$ for $M 1$ and $M 2$ octahedra, respectively for Trip06, and the angle variance for Trip100 is $150.8^{\circ 2}$ and $154.1^{\circ 2}$ (Fig. 6).

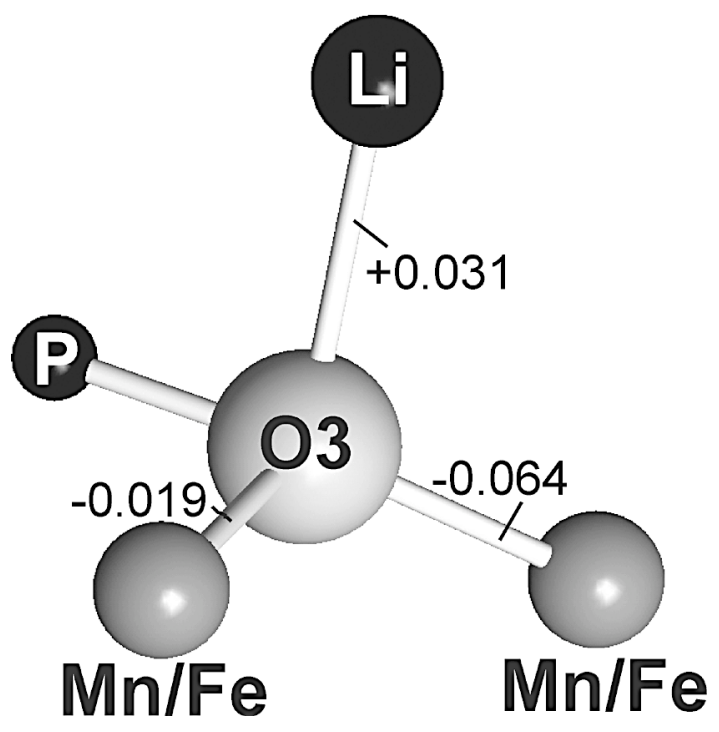

FIG. 4. Geometry of the $\mathrm{O} 3$ site and the bond-length variation that occurs with substitution of $\mathrm{Fe}$ for $\mathrm{Mn}$. 
The angle variance at the $T$ site in the olivine structure varies greatly with the occupant of the $T$ site. The $T$ site shares three edges, one with $M 2$ and two with $M 1$; the $\mathrm{O}-T-\mathrm{O}$ angle of the shared edges contribute $45-80 \%$ of the total angle-variance in tetrahedra in phosphate, silicate, and germanate olivines. Figure 7 a shows the relationship of $T$ cation size to the angle variance in tetrahedra for phosphate, silicate, and germanate olivines. Although there is considerable variation in the angle variance in tetrahedra among olivine-group structures with the same $T$ occupant, the variance in the tetrahedral angle increases with increasing radius of the $T$ cation. The relatively large angle-variance among structures with the same tetrahedrally coordinated cation suggests that the $T$ site in the olivine structure is not

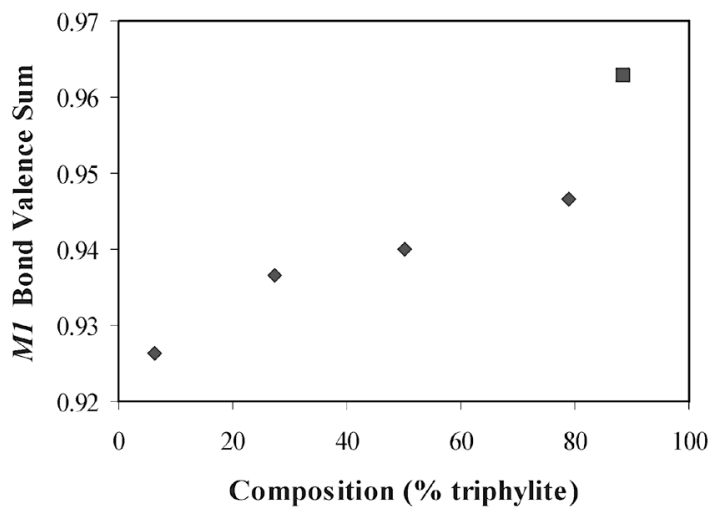

FIG. 5. Plot of the bond-valence sum at the $M 1$ site along the lithiophilite-triphylite join. $\mathbf{\square}$ is the high-Mg sample.

TABLE 5. BOND VALENCE FOR EACH OF THE CATION SITES IN SAMPLES OF THE LITHIOPHILITE - TRIPHYLITE SERIES

\begin{tabular}{|c|c|c|c|c|c|c|}
\hline & Trip06 & Trip27 & Trip50 & Trip79 & Trip89 & Trip100* \\
\hline$M 1-\mathrm{O} 1[2]$ & 0.128 & 0.133 & 0.138 & 0.144 & 0.147 & 0.149 \\
\hline$-02[2]$ & 0.181 & 0.183 & 0.184 & 0.185 & 0.187 & 0.187 \\
\hline$-03[2]$ & 0.154 & 0.152 & 0.148 & 0.144 & 0.147 & 0.142 \\
\hline Sum & 0.926 & 0.937 & 0.940 & 0.947 & 0.963 & 0.954 \\
\hline$M 2-01[1]$ & 0.292 & 0.293 & 0.288 & 0.289 & 0.304 & 0.281 \\
\hline$-02[1]$ & 0.383 & 0.381 & 0.379 & 0.373 & 0.384 & 0.364 \\
\hline$-03 a[2]$ & 0.399 & 0.403 & 0.408 & 0.411 & 0.419 & 0.410 \\
\hline$-03 b[2]$ & 0.271 & 0.267 & 0.260 & 0.256 & 0.262 & 0.247 \\
\hline Sum & 2.014 & 2.014 & 2.003 & 1.996 & 2.050 & 1.959 \\
\hline$-01[1]$ & 1.241 & 1.235 & 1.248 & 1.248 & 1.251 & 1.241 \\
\hline$-02[1]$ & 1.205 & 1.195 & 1.195 & 1.205 & 1.202 & 1.195 \\
\hline$-03[2]$ & 1.154 & 1.154 & 1.151 & 1.151 & 1.151 & 1.139 \\
\hline Sum & 4.754 & 4.738 & 4.745 & 4.756 & 4.755 & 4.714 \\
\hline
\end{tabular}

The bond valences for the $M 2$ site are calculated as weighted sum (\%) of Fe and $\mathrm{Mn}$. * Bond valences for Trip 100 are based on bond distances reported in Streltsov et al. (1993). static and is affected by interactions with connecting polyhedra.

The edge shared between the $M 1$ and $T$ sites along $\mathrm{O} 2-\mathrm{O} 3$ has the greatest effect on variance of the $M 1$ angle. Approximately $45 \%$ of the angle variance of the $M 1$ site results from the two $\mathrm{O} 2-M 1-\mathrm{O} 3$ angles. In silicate olivines, $\mathrm{O} 2-T-\mathrm{O} 3$ is also the most distorted tetrahedral angle (Brown 1980). The edge shared with the $M 2$ octahedron along $\mathrm{O} 1-\mathrm{O} 3$ only has a minor contribution to the overall $M 1$ angle variance.

The $\mathrm{O} 3 \mathrm{a}-M 2-\mathrm{O} 3 \mathrm{a}$ and $\mathrm{O} 3 \mathrm{~b}-M 2-\mathrm{O} 3 \mathrm{~b}$ angles account for $\sim 75$ to $85 \%$ of the angle variance at $M 2$ in forsterite. The $M 2$ octahedron shares one edge with the $T$ site along $\mathrm{O} 3 \mathrm{~b}-\mathrm{O} 3 \mathrm{~b}$, and in phosphate and germanate olivines, this is the most distorted of the $\mathrm{O}-T-\mathrm{O}$ angles. However, the $\mathrm{O} 3 \mathrm{a}-\mathrm{M} 2-\mathrm{O} 3 \mathrm{a}$ angle is also indirectly influenced by the $T$ site. The $\mathrm{O} 3 \mathrm{a}$ and $\mathrm{O} 3 \mathrm{~b}$ positions of the $M 2$ site are determined by the center of symmetry at the $M 1$ site. Thus as the $\mathrm{O} 3 \mathrm{~b}$ atoms of the $M 2$ site move closer together along the $M 2-T$ shared edge, the O3a atoms move further apart.
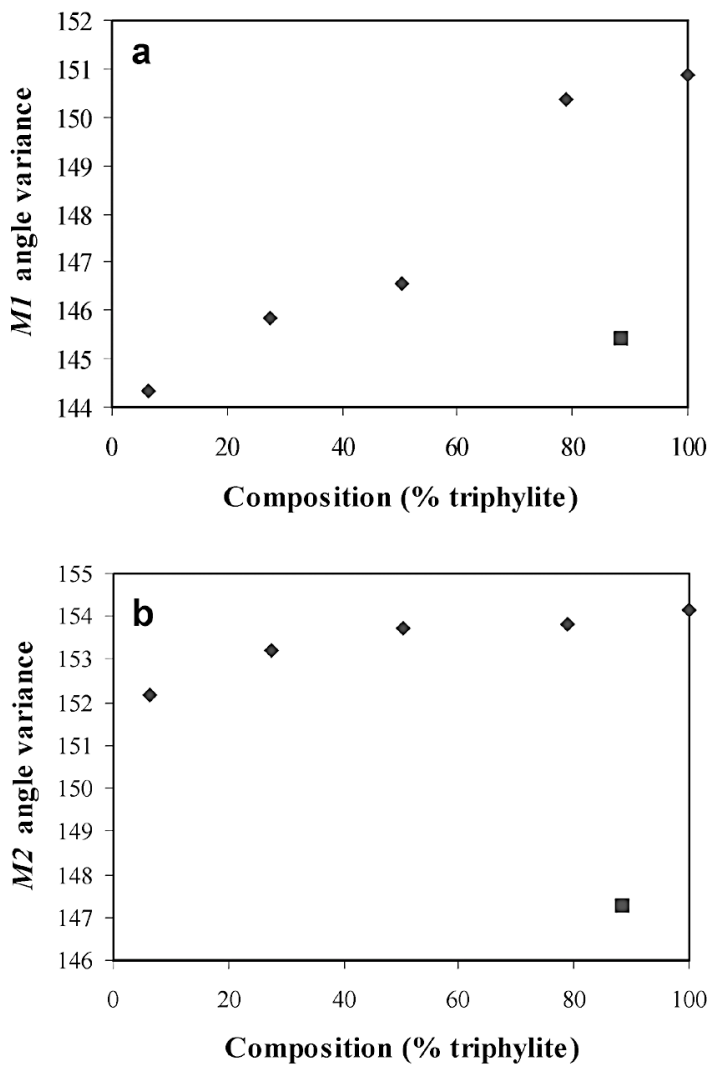

FIG. 6. a-b. Variation in the angle variance at $M 1$ and $M 2$ across the lithiophilite-triphylite series. Data points encompass error of $1 \sigma . \square$ is the high-Mg sample. 
Figure $7 \mathrm{~b}$ displays the ratio of the angle variance at $M 1$ and $M 2$ versus the size of the $T$ cation. Note that the smaller the $T$ cation, the lower the angle-variance ratio. In these examples, the phosphates exhibit an angle variance wherein $M 1<M 2$. The converse is true for the silicate and germanate olivines. However, there are exceptions in the phosphate and silicate olivines in which the angle variance is larger in $M 1$ for phosphate olivines and larger in $M 2$ for silicate olivines. In these phosphate and silicate olivines, there is a large difference in size between the $M 1$ and $M 2$ cation radius ( $\geq 0.17$ $\AA$ ). The difference in cation size between $M 1$ and $M 2$ occupants in natrophilite (Moore 1972), monticellite, and glaucochroite (Lager \& Meagher 1978) is $\geq 0.17 \AA$. In these olivine structures, the site that is occupied by
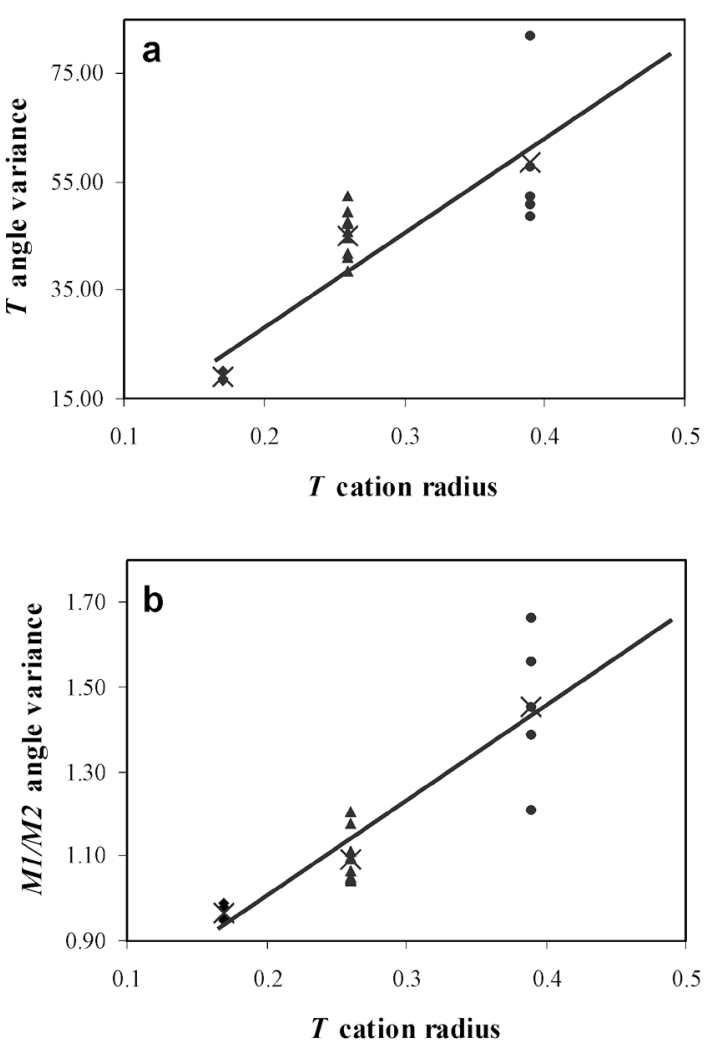

FIg. 7. (a) $T$ angle variance versus $T$ cation radius. Data points encompass error of $1 \sigma$. (b) $M 1 / M 2$ angle variance versus $T$ cation radius. Phosphates : this study: Silicates $\boldsymbol{\Delta}$ : Brown \& Prewitt (1973), Kimata \& Nishida (1987), Kudoh \& Takeda (1986), Lager \& Meagher (1978), Miyake et al. (1987), Morimoto et al. (1974), Motoyama \& Matsumoto (1989), Rajamani et al. (1975), and Takeuchi et al. (1984); Germanates - Belokoneva et al. (1972), Dudka et al. (1986), and Toubol \& Toledano (1987). Average values: X. the larger cation exhibits the larger variance in octahedron angle.

\section{SUMMARY}

The bond-length variations in the $M 1$ and $M 2$ sites of the lithiophilite-triphylite series are correlated with the composition of the $M 2$ site. The bond lengths involving $M 1$ and $M 2$ decrease as the concentration of $\mathrm{Fe}$ increases, with the exception of the $M 1-\mathrm{O} 3$ bond. In addition, the angle variance in the lithiophilite-triphylite series does not show the same trend as in many other examples of the olivine structure-type. In each case, the angle variance of the phosphate olivines is smaller at the $M 1$ octahedron, which is in contrast to the other olivine-group phases examined in this study. However, examination of numerous olivine-type structures demonstrates that if the size difference in the radius of the cation at the $M 1$ and $M 2$ sites is $\geq 0.17 \AA$, the distortion is greater in the octahedron that is occupied by the larger cation.

The results of this study may have a bearing on the development and design of Li-derivative olivine storage cathodes. Thus far, triphylite has been the Li-bearing olivine-group phase most studied for application in rechargeable batteries (Andersson et al. 2000, Chung et al. 2002, Huang et al. 2001, Padhi et al. 1997a, b, Prosini et al. 2001, Scaccia et al. 2003, Yamada et al. 2001a, b, Yang et al. 2002). Critical properties for this application are its electrical and ion (Li) conductivity. Chung et al. (2002) have shown that controlled nonstoichiometry at cation sites combined with doping can increase the electrical conductivity of triphylite to a usable range, and they proposed that the same doping mechanism will apply to other phases having the olivine structure, such as lithiophylite. Structural changes along the lithiophilite-triphylite solid solution, elucidated here, may have an effect on the activation energy for Li diffusion, and thus the rate of diffusion. The activation energy of Li diffusion is directly related to the energy necessary to break all of the $M 1-\mathrm{O}$ bonds. Bond-valence considerations (Fig. 5) indicate that $\mathrm{Li}$ is more strongly underbonded in lithiophylite and thus is less stable in the $M 1$ site in this end-member. Consequently, breaking the six $M 1-O$ bonds will be energetically easier in lithiophylite, which in turn will lead to greater rates of Li diffusion, making lithiophylite a potentially better storage cathode.

\section{ACKNOWLEDGEMENTS}

We are grateful to Anthony Kampf, an anonymous reviewer, and Robert F. Martin for their careful reviews of this manuscript. The study was supported by NSF grant 9814691 . 


\section{REFERENCES}

Andersson, A.S., Thomas, J.O., KalsKa, B. \& Haggstrom, L. (2000): Thermal stability of $\mathrm{LiFePO}_{4}$-based cathodes. Electrochem. Solid-State Lett. 3, 66-68.

Belokoneva, E.L., Ivanov, Y.A., Simonov, M.A. \& Belov, N.V. (1972): Crystal structure of cadmium orthogermanate $\mathrm{Cd}_{2} \mathrm{GeO}_{4}$. Sov. Phys. Crystallogr. 17, 177-179.

BRESE, N.E. \& O'KeEFFE, M. (1991): Bond-valence parameters for solids. Acta Crystallogr. B47, 192-197.

Brown, G.E., JR. (1980): Olivines and silicate spinels. In Orthosilicates (P.H. Ribbe, ed.). Rev. Mineral. 5, 275-381.

\& PREwITT, C.T. (1973): High-temperature crystal chemistry of hortonolite. Am. Mineral. 58, 577-587.

BRown, I.D. (1981): The bond-valence method: an empirical approach to chemical structure and bonding. In Structure and Bonding in Crystals II (M. O'Keeffe \& A. Navrotsky, eds.). Academic Press, New York, N.Y. (1-30).

Chapman, C.A. (1943): Large magnesia-rich triphylite crystals in pegmatite. Am. Mineral. 28, 90-98.

Chung, Sung-Yoon, Blocking, J.T. \& Chiang, Yet-Ming (2002): Electrically conductive phospho-olivines as lithium storage electrodes. Nature Materials 1, 123-128.

DudKA, A.P., KAminskiI, A.A. \& Simonov, V.I. (1986): Refinement of $\mathrm{NaGdGeO}_{4}, \mathrm{NaYGeO}_{4}$, and $\mathrm{NaLuGeO}_{4}$ singlecrystal structures. Phys. Status Solidi A93, 495-502.

Dyar, M.D., Wiedenbeck, M., Robertson, D., Cross, L.R., Delaney, J.S., Ferguson, K., Francis, C.A., Grew, E.S., Guidotti, C.V., Hervig, R.L., Hughes, J.M., Husler, J., Leeman, W.P., McGuire, A.V., Rhede, D., Rothe, H., Paul, R.L., Richards, I. \& Yates, M. (2001): Reference minerals for the microanalysis of light elements. Geostand. Newslett. 25, 441-463.

FINGER, L.W. \& RAPP, G.R., JR. (1969): Refinement of the crystal structure of triphylite. Carnegie Inst. Wash., Yearbook 68, 290-292.

FLEET, M.E. (1974): Distortions in the coordination polyhedra of $\mathrm{M}$ site atoms in olivines, clinopyroxenes, and amphiboles. Am. Mineral. 59, 1083-1093.

Fransolet, A.-M., Antenucci, D., SPeetjens, J.-M. \& Tarte, P. (1984): An X-ray determinative method for the divalent cation ratio in the triphylite-lithiophilite series. Mineral. Mag. 48, 373-381.

FrenZ, B.A. (1997): SDP for Windows Reference Manual. B.A. Frenz and Associates, Inc., College Station, Texas.

Geller, S. \& DuRand, J.L. (1960): Refinement of the structure of $\mathrm{LiMnPO}_{4}$. Acta Crystallogr. 13, 325-331.
HuANG, H., Yin, S.-C. \& NAZAR, L.F. (2001): Approaching theoretical capacity of $\mathrm{LiFePO}_{4}$ at room temperature at high rates. Electrochem. Solid-State Lett. 4, A170-172.

KimatA, M. \& NishidA, N. (1987): The crystal structure of Comonticellite $\mathrm{Ca}_{1.255} \mathrm{Co}_{0.745} \mathrm{SiO}_{4}$ and its significance as a solid solution crystal. Neues Jahrb. Mineral., Monatsh., 160-170.

KudoH, Y. \& TAKEDA, H. (1986): Single crystal X-ray diffraction study on the bond compressibility of fayalite. Physica 139, 333-336.

Lager, G.A. \& Meagher, E.P. (1978): High-temperature structural study of six olivines. Am. Mineral. 63, 365-377.

LANDES, K.K. (1925): The paragenesis of the granite pegmatites of central Maine. Am. Mineral. 10, 355-411.

LuMPKIN, G.R. \& RiBBE, P.H. (1983): Composition, order-disorder and lattice parameters of olivines: relationships in silicate, germanate, beryllate, phosphate and borate olivines. Am. Mineral. 68, 164-176.

Miyake, M., Nakamura, H., Kojima, H. \& Marumo, F. (1987): Cation ordering in Co-Mg olivine solid-solution series. Am. Mineral. 72, 594-598.

Moore, P.B. (1972): Natrophilite, $\mathrm{NaMn}\left(\mathrm{PO}_{4}\right)$, has ordered cations. Am. Mineral. 57, 1333-1344.

Morimoto, N., Tokonami, M., Watanabe, M. \& Koto, K. (1974): Crystal structures of three polymorphs of $\mathrm{Co}_{2} \mathrm{SiO}_{4}$. Am. Mineral. 59, 475-485.

Motoyama, T. \& Matsumoto, T. (1989): The crystal structures and the cation distributions of $\mathrm{Mg}$ and $\mathrm{Fe}$ of natural olivines. Mineral. J. 14, 338-350.

Padhi, A.K., Nanjundaswamy, K.S. \& Goodenough, J.B. (1997a): Phospho-olivines as positive-electrode materials for rechargeable lithium batteries. J. Electrochem. Soc. 144 1188-1194.

Masquelier, C., OKada, S. \& GOODENOUGH, J.B. (1997b): Effect of structure on the $\mathrm{Fe}^{3+}$ $\mathrm{Fe}^{2+}$ redox couple in iron phosphates. J. Electrochem. Soc. 144, 1609-1613.

Prosini, P.P., Zane, D. \& PASQUali, M. (2001): Improved electrochemical performance of a $\mathrm{LiFePO}_{4}$-based composite cathode. Electrochim. Acta 46, 3517-3523.

Rajamani, V., Brown, G.E. \& Prewitt, C.T. (1975): Cation ordering in Ni-Mg olivine. Am. Mineral. 60, 292-299.

Robinson, K., GibBs, G.V. \& RibBe, P.H. (1971): Quadratic elongation: a quantitative measure of distortion in coordination polyhedra. Science 172, 567-570.

Scaccia, S., Carewska, M., Wisniewski, P. \& Prosini, P.P. (2003): Morphological investigation of sub-micron $\mathrm{FePO}_{4}$ and $\mathrm{LiFePO}_{4}$ particles for rechargeable lithium batteries. Mat. Res. Bull. 38, 1155-1163. 
Segeler, C.C., Ulrich, W., KAmpF, A.R. \& Whitmore, R.F. (1981): Phosphate minerals of the Palermo No. 1 pegmatite. Rocks \& Minerals 56, 196-214.

Shainin, V.E. (1946): The Branchville, Connecticut, pegmatite. Am. Mineral. 31, 329-345.

SHANNON, R.D. (1976): Revised effective ionic radii and systematic studies of interatomic distances in halides and chalcogenides. Acta Crystallogr. A32, 751-767.

SMYTH, J.R. (1975): High temperature crystal chemistry of fayalite. Am. Mineral. 60, 1092-1097.

\& HAZEN, R.M. (1973): The crystal structures of forsterite and hortonolite at several temperatures up to $900^{\circ} \mathrm{C}$. Am. Mineral. 58, 588-593.

Streltsov, V.A., Belokoneva, E.L., Tsirelson, V.G. \& HANSEN, N.K. (1993): Multipole analysis of the electron density in triphylite, $\mathrm{LiFePO}_{4}$, using X-ray diffraction data. Acta Crystallogr. B49, 147-153.

TAKeuchi, Y., Haga, N., Hirano, M. \& YamanaKa, T. (1984): High-temperature structural study of olivine-type structures and spinels. Mater. Sci. Earth's Interior, 191-231.
Toubol, M. \& Toledano, P. (1987): Structure du germanate d'indium et de lithium. Acta Crystallogr. C43, 2004-2006.

Yakubovich, O.V., Simonov, M.A. \& Belov, N.V. (1977): The crystal structure of a synthetic triphylite $\mathrm{LiFe}\left[\mathrm{PO}_{4}\right]$ Sov. Phys. Dokl. 22, 347-350.

YAmadA, A. \& Chung, S.-C. (2001): Crystal chemistry of the olivine-type $\mathrm{Li}\left(\mathrm{Mn}_{\mathrm{y}} / \mathrm{Fe}_{1-\mathrm{y}}\right) \mathrm{PO}_{4}$ and $\left(\mathrm{Mn}_{\mathrm{y}} / \mathrm{Fe}_{1-\mathrm{y}}\right) \mathrm{PO}_{4}$ as possible $4 \mathrm{~V}$ cathode materials for lithium batteries. $J$. Electrochem. Soc. 148, A960-967.

\& Hinokuma, K. (2001): Optimized $\mathrm{LiFePO}_{4}$ for lithium battery cathodes. J. Electrochem. Soc. 148, A224-229.

Yang, S., Song, Y., Zavaliu, P.Y. \& Whittingham, M.S (2002): Reactivity, stability, and electrochemical behavior of lithium iron phosphates. Electrochem. Commun. 4, 239244.

Received February 1, 2002, revised manuscript accepted June 24, 2004. 